1 Department of Medical Ethics and Health Policy, Perelman School of Medicine, University of Pennsylvania Philadelphia, USA

Correspondence to: $\mathrm{N}$ Scheinerman naomisch@upenn.edu

Cite this as: BMJ 2021;373:n1207 http://dx.doi.org/10.1136/bmi.n1207 Published: 26 May 2021

\section{What does it mean to engage the public in the response to covid-19?}

Naomi Scheinerman and Matthew McCoy explain how governments and other authorities should
respond to calls for public engagement in covid-19 response and recovery

Naomi Scheinerman, ${ }^{1}$ Matthew McCoy ${ }^{1}$

Over the past year, numerous individuals and institutions have called on governments and other authorities to engage, involve, or include the public in covid-19 response and recovery efforts. ${ }^{12}$ In the United Kingdom, for instance, the Nuffield Council on Bioethics urged the government to ensure that key decisions about covid-19 are "taken with the widest possible engagement across all sections of society."3 In the United States, a coalition of more than 100 voluntary associations pressed government agencies to "recommit to, and not retrench from, their duty to include the public" in policy making processes related to the pandemic. ${ }^{4}$

These calls follow a long campaign to increase public engagement in urgent or controversial matters of health and science policy and make an intuitively compelling appeal to democratic values. ${ }^{5}$ They rest on the premise that consequential decisions about the response and recovery from covid-19 should not be left to experts but should instead be subject to inclusive debate and deliberation. Public engagement is particularly important during the covid-19 pandemic when the effectiveness of measures such as masking, social distancing, and vaccination requires cooperation and trust across all sectors of society.

However, as with previous calls for public engagement, the meaning of "engagement" and its practical implications for covid-19 response and recovery are complex and at times ambiguous. ${ }^{6} \mathrm{We}$ examine the different types of demands found in calls for public engagement in pandemic decision making and explain how to meet them (table 1). We focus on the responsibilities of governments because their decisions have far reaching social consequences, but institutions such as hospital systems, schools, corporations, and universities also make decisions that profoundly affect the communities they serve and should engage affected communities in their decision making. 
Table 1 | Public engagement on response to covid-19

\begin{tabular}{|c|c|c|}
\hline Elements of engagement & Responsibilities & Examples \\
\hline Transparency & $\begin{array}{l}\text { - Hold regular press briefings on policy and planning decisions } \\
\text { - Promptly publish relevant data and draft proposals online } \\
\text { - Partner with local stakeholders and community organisations } \\
\text { to deliver targeted messaging }\end{array}$ & $\begin{array}{l}\text { - Norway's government developed a covid-19 information } \\
\text { website that includes information on national response } \\
\text { measures as well as a special section directed towards families } \\
\text { and children and a section where users can follow live press } \\
\text { conferences } 7 \\
\text { - Canada's Department of Justice created a webpage that allows } \\
\text { citizens to easily access "all of the legislative and other } \\
\text { measures related to covid-19"7 }\end{array}$ \\
\hline Ethical reasoning & $\begin{array}{l}\text { - Articulate the ethical values and frameworks informing policy } \\
\text { decisions } \\
\text { - Acknowledge trade-offs between competing goods and } \\
\text { interests and explain how they will be navigated }\end{array}$ & $\begin{array}{l}\text { - US Centers for Disease Control and Prevention's advisory } \\
\text { committee on immunization practices uses an open process to } \\
\text { develop and revise its ethical framework for vaccine allocation. } \\
\text { All committee meetings are open to the public, and meeting } \\
\text { minutes and archived webcasts are available online; members } \\
\text { of the public are invited to submit written and oral comments } \\
\text { to the committee; and the committee includes } 30 \text { non-voting } \\
\text { representatives from liaison organisations intended to "facilitate } \\
\text { engagement with professional medical and public health } \\
\text { organisations and other stakeholders and partners" } 8\end{array}$ \\
\hline Informal deliberation & $\begin{array}{l}\text { - Foster informal deliberation by meeting demands for } \\
\text { transparency } \\
\text { - Respond to questions and concerns emerging from the public } \\
\text { sphere } \\
\text { - Remain mindful of underlying power dynamics with the } \\
\text { potential to influence public discourse and seek out } \\
\text { under-represented voices }\end{array}$ & $\begin{array}{l}\text { - Several governments, including those of Estonia, Korea, } \\
\text { Norway, Canada, Germany, and Italy, have developed apps, } \\
\text { websites, and portals for citizens to call or submit questions } \\
\text { and comments, including proposals for ideas, feedback, or } \\
\text { services } \\
\text { - In Providence, Rhode Island, city officials worked with local } \\
\text { neighbourhood and faith leaders to arrange meetings where } \\
\text { members of minority communities could raise questions and } \\
\text { concerns about vaccination to state health professionals } 10\end{array}$ \\
\hline Formal deliberation & $\begin{array}{l}\text { - Consider convening mini-publics when the considered opinions } \\
\text { of a diverse group of lay participants would help address a } \\
\text { focused policy challenge or question } \\
\text { - Clearly communicate how the outputs of mini-publics would } \\
\text { be used to inform decision making }\end{array}$ & $\begin{array}{l}\text { - Scotland's Citizen Assembly, already in existence before the } \\
\text { pandemic, turned its attention to discussing the effect of } \\
\text { covid-19 and how it may influence views on what is important } \\
\text { for the future of the country }{ }^{11} \\
\text { France set up a } 35 \text { person citizens' panel to help steer } \\
\text { government strategy on covid-19 vaccinations }{ }^{12}\end{array}$ \\
\hline
\end{tabular}

\section{Transparency}

Common to almost all calls for public engagement in covid-19 response and recovery is a demand for transparency on the part of government officials and other authorities responding to the pandemic. As the Nuffield Council wrote in an open letter to the UK prime minister, government should "show the public what it is doing and thinking across the range of issues of concern." ${ }^{3}$ But a review of decision making related to covid-19 in 24 countries found "little transparency regarding whom decision making bodies are consulting as their source of advice and information."13

Transparency involves the flow of information from government to the public. It does not require that members of the public take an active hand in responding to the crisis but is critical to enabling more direct involvement in at least two ways. Firstly, knowledge of how government agencies are managing the pandemic gives individuals, civil society organisations, and businesses the information they need to play their parts in pandemic response and recovery. Secondly, transparency allows individuals and institutions outside of government to scrutinise government plans, highlight errors, criticise misguided policies, and recommend alternative courses of action. Several government guidelines on mask wearing, testing, and other areas of pandemic response have been constructively revised in response to public criticism. ${ }^{14}$

Transparency can also build public trust in government. An investigation of public perceptions of the UK government's covid-19 response found that "the extent to which a government may be able to foster public trust in their [sic] responses to pandemics appears to be closely linked to the coherence and transparency of their communication strategies.” ${ }^{15}$ Notably, however, the study also found "significant differences in levels of trust across geographical, income and educational backgrounds," which suggest the need to "develop measures such as targeted community engagement that tailor messaging and public deliberation to the realities faced by particular social groups.” 15

Municipal and regional governments have a critical role in delivering this type of locally targeted outreach. In the US, several city leaders have partnered with local community and faith based organisations to counter concerns about vaccines among communities with "historical experiences with discrimination." 10 This is a successful example of a complementary relationship between national and local leaders. While national health agencies have the resources to synthesise scientific information into guidelines, local officials need to tailor and explain guidelines to their communities. ${ }^{16}$

\section{Ethical reasoning}

Beyond pushing for transparency about the substance of policy decisions and planning around covid-19, the Nuffield Council called on governments to "set out the ethical considerations" underlying these decisions. ${ }^{3}$ This demand is based on the principle that government policies must be justifiable to those affected by them, particularly those negatively affected by a decision.

While it's tempting to believe that effectively managing the pandemic is simply a matter of following the science, ${ }^{17} \mathrm{critical}$ questions such as when and under what conditions to reopen businesses or how to allocate vaccine doses are value laden, involving trade-offs between competing goods and interests. ${ }^{18}$ Authorities need to justify the selection of a particular course of 
action not just in technical terms but in ethical ones, and commit to principled decision making.

This promotes accountability by enabling members of the public to pressure authorities to live up to their stated principles. For example, criticisms of the UK government's handling of covid-19 in adult social care settings noted that although the government espoused a commitment to be "transparent about why decisions are made and who is responsible for making and communicating them," it failed to provide "detail on how a decision was taken to leave the most vulnerable people in society and their carers unprotected."19

Providing ethical reasoning can also foster constructive discussions about how best to realise stated principles. For example, several authorities have emphasised that vaccine allocation should prioritise disadvantaged populations. ${ }^{20}$ By clearly articulating this aim, these authorities have prompted broader discussions about how to conceptualise disadvantage in the context of covid-19, and how to achieve the goal of prioritising disadvantaged populations. This debate has led to concrete proposals such as using a social vulnerability index to prioritise areas for vaccine allocation. ${ }^{20}$

International organisations, national bioethics commissions, and others have published ethical frameworks that can help governments and other authorities to articulate the principles guiding policy decisions and trade-offs. ${ }^{21-23}$ These frameworks identify ethical considerations raised by various covid-19 response measures and provide practical guidance for weighing these considerations in concrete cases. Ultimately, however, it is the responsibility of authorities to work with relevant stakeholders to develop and communicate principles guiding pandemic response measures. $^{18}$

\section{Informal deliberation}

While some calls for public engagement in the covid-19 response emphasise governments' responsibility to share information with the public, others emphasise ways that the public should be actively involved. These often appeal to ideals of deliberative democracy, arguing that citizens can and should engage in politics not just by voting in elections but through ongoing debate and discussion. This can happen through "informal" types of deliberation across civil society and "formal" deliberation involving structured dialogue in institutional settings. ${ }^{24}$

Informal deliberation about covid-19 encompasses activities ranging from small scale conversations in online forums to opinion articles in national media and organised demonstrations. Informal deliberation can enhance institutional decision making by contributing information and perspectives that are not represented by experts and policy makers. As New York City moved to lift restrictions on businesses, for example, essential workers, advocates, and unions organised to demand workplace protections and to pressure state and local officials to enact regulations requiring employers to fully comply. ${ }^{25}$ By participating in this sort of deliberation, citizens communicate the challenges they face from covid-19 and apply political pressure to authorities responsible for addressing those challenges.

Governments have a central role in fostering informal deliberation by meeting demands for transparency by responding to questions and concerns emerging from the public sphere. But it is also critical that they remain aware of how underlying inequalities and power dynamics shape public discourse. Informal deliberation often amplifies the voices of those with greater resources and access to media platforms while crowding out the voice of marginalised groups that have been hardest hit by the pandemic and whose voices are crucial to designing equitable policy responses. ${ }^{26}$ Similarly, while events like virtual townhall meetings can provide a forum for community members to share their concerns and experiences, they perpetuate disparities in access to technology and the internet, widening existing gaps. ${ }^{27}$

Given these structural inequalities, responsible informal deliberation requires seeking out perspectives of disadvantaged groups that are often under-represented in the media, public meetings, and digital platforms. Doing so requires soliciting input across "multiple, accessible channels," including community events and faith based gatherings. ${ }^{28}$ Authorities should work with non-profit and academic organisations that have compiled testimonies from disadvantaged communities. In the UK, for example, National Voices, a coalition of organisations "supporting people with physical and mental health problems and disability and those who are facing inequality or discrimination," collects and publishes first person accounts of people's challenges and experiences during covid-19. ${ }^{29}$ In the US, the Black America and Covid-19 Project collects and publishes evidence of the effect of covid-19 on the Black community with the goal of creating "material for teaching and learning about the contemporary effects of covid-19 among Black communities as it is tied to the historical legacy of race in America."30

\section{Formal deliberation}

Finally, some calls for public engagement urge governments not simply to foster or engage with informal deliberation, but to convene formalised deliberative bodies, also called mini-publics. ${ }^{31}$ These are small groups of people (from around 10 to several hundred) who are selected, often at random, to engage in facilitated deliberation about policy topics related to covid-19.

Formal deliberative mechanisms create environments in which citizens with different backgrounds and identities are placed on equal footing and given the opportunity to learn from experts and share their perspectives on complex policy matters. Ideally, participants in mini-publics refine and revise their views through conversation with their peers, such that their recommendations or outputs can be said to reflect the "considered views" 32 of participants.

Encouraged by recent successes of mini-publics, 33 some believe that formal deliberation can inform covid-19 responses. In the UK, for example, local officials commissioned a 36 member citizen's panel to consider evidence and weigh trade-offs in different recovery plans before forwarding a set of recommendations to the local recovery authority. ${ }^{34}$ Similarly, Oregon convened a seven day citizens' assembly which developed a set of core principles and actionable recommendations to guide the state's pandemic response and recovery plans with respect to housing and education. 35

Despite their potential to capture a range of perspectives and to generate nuanced and considered feedback, ${ }^{36}$ mini-publics require substantial time, planning, and financial resources to succeed. This limits their use in responding to urgent problems during a public health crisis, and they should not be viewed as a substitute for other aspects of public engagement.

Before convening a mini-public, governments should identify particular questions or policy decisions for which the considered opinions of a diverse group of lay participants would be illuminating and how those opinions would be used to inform policy. In light of their strengths and limitations, mini-publics may be best suited to reviewing failures, success, and lessons from the current pandemic in order to better prepare for the next emergency. ${ }^{37}$ 
The ongoing process of responding to and recovering from the covid-19 pandemic should not be managed by policy makers and experts alone. It will continue to require extraordinary levels of communication and coordination across all levels of society. Governments and other authorities can realise these goals only by recognising and taking steps to meet demands embedded in calls for public engagement.

\section{Key messages}

- Growing numbers of voices have called on governments and other authorities to engage the public in pandemic response and recovery efforts

- Transparency about decisions and their ethical framework is essential for engagement

- Informal discussion through media and public meetings can help ensure success of interventions

- Formal deliberation methods are slower and may be more suited to longer term planning

Contributors and sources: NS is a democratic theorist specialising in mini-public deliberative engagement, and $\mathrm{MMCC}$ is a bioethicist with a background in political theory.

Competing interests: We have read and understood BMJ policy on declaration of interests and have no interests to declare.

\section{Provenance and peer review: Not commissioned; externally peer reviewed.}

NS was supported by a T32 postdoctoral training grant from the National Human Genome Research Institute to the University of Pennsylvania (T32HG009496).

1 Richards T, Scowcroft HBMJ's international patient and public advisory panel. Patient and public involvement in covid-19 policy making. BMJ2020;370:m2575.

doi: 10.1136/bmj.m2575. pmid: 32611571

2 Norheim OF, Abi-Rached JM, Bright LK, etal. Difficult trade-offs in response to COVID-19: the case for open and inclusive decision making. Nat Med 2021;27:10-3.

doi: 10.1038/s41591-020-01204-6 pmid: 33340033

3 Nuffield Council on Bioethics. Covid-19 and the basics of democratic governance. 2020. https://www.nuffieldbioethics.org/news/statement-covid-19-and-the-basics-of-democratic-governance

4 Kelley J. Governments must commit to transparency during covid-19 crisis. Electronic Frontier Foundation 2020. https://www.eff.org/deeplinks/2020/03/governments-must-commit-transparency-during-covid-19-crisis

5 McCoy MS, Emanuel EJ. In: Lever A, Poama A, eds. The Routledge handbook of ethics and public policy. Routledge, 2018.

6 Juengst ET. Crowdsourcing the moral limits of human gene editing? Hastings Cent Rep 2017:47:15-23. doi: 10.1002/hast.701 pmid: 28543411

7 Open Government Partnership. Collecting open government approaches to covid-19. 2021. https://www.opengovpartnership.org/collecting-open-government-approaches-to-covid19/\#

8 McClung N, Chamberland M, Kinlaw K, etal. The advisory committee on immunization practices' ethical principles for allocating initial supplies of covid-19 vaccine-United States, 2020. MMWR Morb Mortal Wkly Rep 2020;69:1782-6. doi: 10.15585/mmwr.mm6947e3 pmid: 33237895

9 OECD. The territorial impact of covid-19: managing the crisis across levels of government. 2020 https://www.oecd.org/coronavirus/policy-responses/the-territorial-impact-of-covid-19-managingthe-crisis-across-levels-of-government-d3e314e1/

10 Gorton L, Elorza J, Buol R. Mayors on equity and covid vaccines: messaging, partnership and confidence. National League of Cities. 2021. https://www.nlc.org/article/2021/02/19/mayors-onequity-and-covid-vaccines-messaging-partnership-and-confidence/

11 Citizens' Assembly of Scotland. Reflecting on the impact of covid. 2020. https://www.citizensassembly.scot/report-assembly/chapter-four-assembly-vision/reflecting-impact-covid

12 Casassus B. France turns to citizens' panel to reduce vaccine skepticism. Science 2021;371:763-4. doi: 10.1126/science.371.6531.763 pmid: 33602833

13 Rajan D, Koch K, Rohrer K, etal. Governance of the Covid-19 response: a call for more inclusive and transparent decision-making. BMJ Glob Health 2020;5:e002655. doi: 10.1136/bmigh-2020-002655. pmid: 32371570

14 Fung A. Covid-19 requires more democracy, not less. Boston Review2020 Apr 23. http://bostonreview.net/politics/archon-fung-covid-19-requires-more-democracy-not-less

15 Enria L, Waterlow N, Rogers NT, etal. Trust and transparency in times of crisis: results from an online survey during the first wave (April 2020) of the COVID-19 epidemic in the UK. PLOS One 2021;16:e0239247. doi: 10.1371/journal.pone.0239247. pmid: 33591985
16 Wen LS, Sadeghi NB. Addressing racial health disparities in the covid-19 pandemic: immediate and long-term policy solutions. Health Affairs blog, 20 Jul 2020. https://www.healthaffairs.org/do/10.1377/hblog20200716.620294/full/

17 Diya C. Coronavirus today: science will save us. Los Angeles Times 2020 Apr 13. https://www.latimes.com/science/newsletter/2020-04-13/coronavirus-today-science-will-saveus-coronavirus-today

18 Fritz Z, Huxtable R, Ives J, Paton A, Slowther AM, Wilkinson D. Ethical road map through the covid-19 pandemic. BMJ 2020;369:m2033. doi: 10.1136/bmj.m2033 pmid: 32439751

19 McCullough M. Ethical decision making in a pandemic: where are the voices of vulnerable people?BMJ2020;369:m2406. doi: 10.1136/bmj.m2406 pmid: 32561520

20 Schmidt H, Pathak P, Sönmez T, Ünver MU. Covid-19: how to prioritize worse-off populations in allocating safe and effective vaccines. BMJ 2020;371:m3795. doi: 10.1136/bmj.m3795 pmid: 33020072

21 UNESCO provides ethical frameworks to covid-19 responses. 4 May 2020. https://en.unesco.org/news/unesco-provides-ethical-frameworks-covid-19-responses

22 WHO. Ethics and COVID-19: resource allocation and priority-setting. 2020. https://www.who.int/ethics/publications/ethics-and-covid-19-resource-allocation-and-prioritysetting/en/

23 Dawson A, Isaacs D, Jansen M, etal. An ethics framework for making resource allocation decisions within clinical care: responding to covid-19. J Bioeth Inq 2020;17:749-55. doi: 10.1007/s11673-020-10007-w pmid: 32840833

24 Hendriks CM. Integrated deliberation: reconciling civil society's dual role in deliberative democracy. Polit Stud 2006;54:486-508doi: 10.1111/j.1467-9248.2006.00612.x.

25 What happens if I get sick again?": Essential workers seek expanded protections. NBC News 2020 Jul 9. https://www.nbcnews.com/news/us-news/what-happens-if-i-get-sick-again-essentialworkers-seek-n1233327)

26 Brown M. Deliberation and representation. In: Bächtiger A, Dryzek JS, Mansbridge J, Warren ME, eds. The Oxford handbook of deliberative democracy. Oxford University Press, 2018:171-86.

27 Aurbach EL, DeVaney J. Public engagement in the time of covid-19. Inside Higher Ed, 16 Apr 2020 https:/www.insidehighered.com/blogs/learning-innovation/public-engagement-time-covid-19

28 National Academies for Science, Engineering, and Medicine. Strategies for public engagement to combat mistrust and build covid-10 vaccine confidence. 2021. https://www.nap.edu/resource/26068/interactive/vulnerable-communities.html

29 National Voices. Our covid voices. 2021. https://ourcovidvoices.co.uk/

30 Black American experiences during the covid-19 pandemic. 2021. https://guides.library.harvard.edu/BlackCovid/home

31 Ryan M, Smith G. Defining mini-publics. In: Grönlund K, Bächtiger A, Setälä M, eds. Deliberative mini-publics: involving citizens in the democratic process. ECPR Press, 2014: 9-26.

32 Hendriks CM.Coupling citizens and elites in deliberative systems: the role of institutional design. Eur J Polit Res 2015;55:43-60doi: 10.1111/1475-6765.12123

33 Farrell DM, Suiter J, Harris C. 'Systematizing' constitutional deliberation: the 2016-18 citizens' assembly in Ireland. Ir Polit Stud 2019;34:113-23.

34 Citizens' panel member talks about hopes for the West Midlands. Phoenix 2020 Jun 25. https://thephoenixnewspaper.com/citizens-panel-member-talks-about-hopes-for-the-westmidlands)

35 Oregon citizens' assembly on covid-19 recovery. 2021. https://participedia.net/case/7114

36 Mansbridge J. Deliberative polling as the gold standard. Good Soc PEGS 2010;19:55-62doi: 10.5325/goodsociety.19.1.0055

37 White S. A people's inquiry? Deliberative democracy and the pandemic. Compass 2020. https://www.compassonline.org.uk/publications/a-peoples-inquiry 